\title{
Human Resources Capacity Building in Accessible Tourism in Egypt
}

Meril Ibrahem Moris ${ }^{1}$, Heba Atef Alakhras, Neveen Galal Eid, Mohamed Abdel el rahman Higazy

Tourism Studies Department, Faculty of Tourism and Hotels, Suez Canal University.

\begin{tabular}{|c|c|}
\hline ARTICLE INFO & Abstract \\
\hline Keywords: & This research aims to evaluate the existing awareness and attitudes \\
\hline Accessible & of tourism staff towards Accessible Tourism and underline the \\
\hline Tourism; Attitudes; & urgent need for training on Accessible Tourism, since awareness \\
\hline Awareness; human & and training are the most effective means of changing attitudes. \\
\hline resources. & Reviewing the literature revealed lack of awareness of Accessible \\
\hline & $\begin{array}{l}\text { travel in addition to negative attitudes of human resources towards } \\
\text { this tourism. Data were collected through semi-structured interviews }\end{array}$ \\
\hline (JAAUTH) & with different stakeholders related to Accessible Tourism issue. This \\
\hline Vol. 17, No. 2, & is followed by a questionnaire to human resources in travel agencies \\
\hline (2019), & and hotels. This research contributes to improving the quality of the \\
\hline PP.82-89. & $\begin{array}{l}\text { experience of People with disabilities and seniors in the Egyptian } \\
\text { context. }\end{array}$ \\
\hline
\end{tabular}

\section{Introduction}

Accessible Tourism is a large and profitable market; however, it has been ignored by the tourism sector a long time (UNWTO, 2005). Tourists with disabilities are greatly excluded from leisure activities.

Capacity building as a definition is considered as an integrated and systematic approach to develop and continuously improve governmental, organizational and individual capabilities and competencies (Mallick, 2013). while Groot and Molen (2000) and Yamoah (2014) defined human resources capacity building as the development of knowledge, skills and attitudes of individuals and groups of people relevant to design, development, management and maintenance of institutional and operational infrastructures and processes .

\section{Literature Review of Accessible Tourism}

\section{Accessible Tourism definition:}

"Accessible Tourism is a form of tourism that involves a collaborative process among different stakeholders that enables tourists with special access requirements, including (hearing, vision, mobility and cognitive dimensions of access) to function independently with dignity and equity and through the delivery of universally designed tourism services, products, and environments"(Buhalis and Darcy 2011; Michopoulou et al., 2015). While UNWTO (2016) stated that the concept of "Accessible Tourism" refers to:" the environment and tourism, products and services adaptation to enable access, use and enjoyment by all participants, under the principles of Universal Design".

\section{The hardest barriers facing Accessible Tourism:}

Many researchers argued that the common complaint about tourism and travel staff is the negative attitudes towards People with disabilities and seniors (e.g. Gillovic and Mcintosh, 2015; Zheng et al., 2016; Kaganek et al., 2017).

Others declared that such negative attitudes are largely due to the lack of awareness and knowledge and consequent misunderstandings and training concerning legislation (Daruwalla and Darcy, 2005; ENAT and European commission, 2013).

\footnotetext{
${ }^{1}$ Merilibrahem@gmail.com
} 


\section{The significance of building the capacity of human resources in tourism sector in Accessible Tourism issue:}

Darcy and Pegg (2011) reported that having accessible premises is not everything but it is just a starting point for providing services for tourists with disabilities, but if labors themselves are not well- trained to provide appropriate customer service, tourist's needs will not be adequately addressed.

Seniors and tourists with disabilities can experience barriers at any point in their visit. It is therefore clear that all human resources at any part of the "visitor journey" must be equipped with knowledge and skills to assist and accommodate all tourists with equal attention, respect and support, as and when needed (European commission, 2010).

\section{Accessible Tourism chain:}

It is possible to liken chain rings to the transfer of the tourist of special requirements to the hotel, being welcomed by hotel employees (the employees should be well-educated about the matter of welcoming the guests and communicating with them), accommodation, attending tours, shopping during tours (souvenirs, food- drinks, etc.) and return the tourists to their countries. Thus, accessibility is not just related to a ring of chain, but it is related to all matters (Özogul and Baran, 2016).

\section{Necessary competences for delivering Accessible Tourism: -}

The competences needed will be divided into: competences needed for the front line staff (reception, reservation, restaurants, etc.), managers, travel agencies, tour guides and airport staff.

\section{The qualifications needed for the front line staff "Accommodation sector:}

The UNWTO (2013) listed the following qualifications needed for the front line staff in general "Accommodation sector" dealing with disability:

- Demonstrating knowledge of using appropriate language when referring to tourists with disabilities (e.g. using the correct terminology), having a clear understanding of the service and the facilities that the business can offer, and also being aware of different disabilities that customers may have and demonstrating knowledge of the facilities in the local community that are accessible to tourists with disabilities (including attractions, accommodation, restaurants and transport).

\section{The qualifications needed for the hotel managers:}

The DCMS Accessible Tourism stakeholder forum (2012) declared that managers should have the following qualifications:

1- Reviewing the way in which staff is using appropriate language when dealing with seniors and guests with disabilities (using the correct terminology) and how best this can be mainstreamed into business culture and practice.

2-Stating the importance of developing customer service standards to Accessible Tourism by analyzing the following points:

A-What we mean by Accessible Tourism (disability, seniors etc.)

B -How to evaluate customer service performance for tourists with disabilities and take action to improve performance when necessary. 
The qualifications needed for the tour guides dealing with Accessible Tourism market: ENAT (2007) pointed that the use of models and tactile maps for people with visual impairments and interpretive techniques for explaining an historical monument to tourists with learning difficulties that must be included in the training of tourist guides, referring to other senses than sight, such as smelling, moving, tactile sensations and hearing when guiding tourists with a visual impairment.

\section{The qualifications needed for airport staff "transportation sector"}

The European commission (2014) listed the following points as basic qualifications that airport staff "transportation sector "must acquire:

A- A practical experience at a senior level in the assistance of travelers with disabilities and seniors.

B- Knowledge and experience in instructional techniques.

C- Available expertise and receive feedback from disability organizations.

\section{Research objectives:}

The research aims at:

1- Evaluating the attitudes of the working force in the tourism sector in Egypt towards Accessible Tourism.

2- Assessing the disability awareness training programs of the Egyptian tourism sector.

3- Investigating the required skills and qualifications for effective human resources attitudes towards Accessible Tourism in the Egyptian context.

\section{Research question:}

What is the current level of attitudes and awareness of Accessible Tourism as well as training programs of the Egyptian human resources in the travel and tourism sector?

\section{Research methodology:}

\section{- The theoretical method:}

The research relied on textbooks, reports, scientific journals and scientific professional researchers related to the issue.

\section{- The field study:}

The field work aimed at collecting stakeholders' perspectives about Accessible Tourism; through:

1-Semi-structured interviews to assess the current status of Accessible Tourism training programs in the Egyptian tourism sector, and detect the steps taken to minimize the barriers facing Accessible Tourism.

The interview styles have been adjusted to the different persons that were interviewed and the different situations. The 62 interviews conducted on the face to face and telephone basis, the interviews conducted with top managers and decision makers in public and private sectors.

2-Questionnaires were distributed to a sample of human resources in travel agencies, hotels; the aim of the questionnaire is to:

Evaluate the existing attitudes towards Accessible Tourism; explore the awareness level of the tourism staff of Accessible Tourism and identify the mechanisms for effective Accessible Tourism training through conducting Training Needs Assessment (TNA).

The questionnaire included four parts; the first part served the aim of collecting data about the organization name, years of experience in tourism sector. The second part served the 
purpose of collecting data about the human resources awareness about disability issues and Accessible tourism. The third part included questions needed to evaluate the existing attitudes towards PWDs and seniors; the questionnaire items were obtained from the following scales: Interactions with Disabled person's scale (IDP) which is a 20 -item Likert scale that is designed to measure the attitudes toward people with disabilities by assessing the levels of discomfort in social interactions as a basic factor detecting negative attitudes (Gething, 1992) while the other scale used is: The Attitudes towards Disabled Persons (ATDP) scale developed by Yuker et al. in 1960.

While the last part of the questionnaire included questions needed to identify the mechanisms for effective Accessible Tourism training through conducting training needs assessment (TNA) in Accessible Tourism field within the Egyptian context.

\section{The use of mixed methods:}

The mixed method focuses on collecting, analyzing, and mixing both quantitative and qualitative data in a single or a series of studies. Its basic premise is to use qualitative and quantitative approaches together, the thing which provides a far better understanding of research issues than either approach alone (Cameron, 2011).

\section{Sampling technique and sample size:}

The study adopts random sampling (where every participant has an equal chance of being selected). The field study included hotel employees and travel agencies employees. The total response rate to the study is 205 classified into 126 of hotel employees and 58 travel agencies employees.

\section{Data analysis of quantitative data}

The research used some descriptive statistical the mean, S.D, percentage (\%), level of verification.

\section{Table 1}

The awareness of the Egyptian human resources in the tourism sector towards Accessible Tourism

\begin{tabular}{|l|c|c|c|c|c|c|c|c|c|c|}
\hline \multirow{2}{*}{ Item } & \multicolumn{4}{|c|}{ Hotel employees } & \multicolumn{5}{c|}{ Travel agencies employees } \\
\cline { 2 - 11 } & mean & $\mathbf{S . D}$ & $\%$ & $\begin{array}{c}\text { Level of } \\
\text { verification }\end{array}$ & order & mean & S.D & \%erification & order \\
\hline $\begin{array}{l}\text { 1-I am totally aware of how to } \\
\text { deal in an effective and tailored } \\
\text { way with people with disabilities } \\
\text { and seniors }\end{array}$ & $\mathbf{2 . 2 6}$ & $\mathbf{1 . 3 3}$ & $\mathbf{4 5 . 2}$ & Low & 5 & 3.03 & 1.02 & 60.6 & average & 1 \\
\hline $\begin{array}{l}\text { 2-I experienced being unaware } \\
\text { of how to offer help to people } \\
\text { with disabilities and senior } \\
\text { guests }\end{array}$ & $\mathbf{2 . 6 4}$ & $\mathbf{1 . 4 8}$ & $\mathbf{5 2 . 8}$ & Average & 3 & 2.86 & 1.50 & 57.2 & Average & 2 \\
\hline $\begin{array}{l}\text { 3-I am totally aware of all } \\
\text { barriers encountered by people } \\
\text { with disabilities and seniors }\end{array}$ & $\mathbf{2 . 8 7}$ & $\mathbf{1 . 6 2}$ & $\mathbf{5 7 . 4}$ & Average & 1 & 2.84 & 1.53 & 56.8 & average & 3 \\
\hline $\begin{array}{l}\text { 4- I am totally aware of Egyptian } \\
\text { legislation and policies related to } \\
\text { the rights of people with } \\
\text { disabilities to transfer and the } \\
\text { availability of trained staff to } \\
\text { serve them effectively }\end{array}$ & $\mathbf{2 . 7 4}$ & $\mathbf{1 . 5 2}$ & $\mathbf{5 4 . 8}$ & Average & 2 & 2.79 & 1.50 & 55.8 & average & 4 \\
\hline $\begin{array}{l}\text { 5- The property is applying the } \\
\text { full access requirements }\end{array}$ & $\mathbf{2 . 6 3}$ & $\mathbf{1 . 4 4}$ & $\mathbf{5 2 . 6}$ & Average & 4 & - & - & - & - & - \\
\hline Total mean & $\mathbf{2 . 7 4}$ & $\mathbf{1 . 4 7}$ & $\mathbf{5 2 . 6}$ & Average & 2.88 & 1.38 & 57.6 & average \\
\hline
\end{tabular}

It is evident from table (1) that the highest response of staff awareness of Accessible Tourism came to the statement (3) which states I am totally aware of all barriers 
encountered by people with disabilities while (1) which states I am totally aware of how to deal in an effective and tailored way with PWDs and seniors and the highest response of travel agents staff awareness of Accessible Tourism came to the statement (1) which states I am totally aware of how to deal in an effective and tailored way with PWDs and seniors. This result is against the results of prior studies such as (Daruwalla and Darcy, 2005; ENAT and European commission, 2013) which states that there is a clear lack of awareness among tourism employees of the different barriers that people with disabilities may encounter in their properties.

\section{The attitude of human resources towards people with disabilities and seniors:}

\section{The table 2}

Shows the mean, S.D, Percent (\%) and level of verification related to attitudes of the Egyptian human resources in tourism sector towards Accessible Tourism as the follows:

\begin{tabular}{|c|c|c|c|c|c|c|c|c|c|c|}
\hline \multirow[b]{2}{*}{ Item } & \multicolumn{5}{|c|}{ Hotel employees } & \multicolumn{5}{|c|}{ Travel agencies employees } \\
\hline & Mean & S.D & $\%$ & $\begin{array}{c}\text { Level of } \\
\text { verification }\end{array}$ & order & mean & S.D & $\%$ & $\begin{array}{c}\text { Level of } \\
\text { verification }\end{array}$ & order \\
\hline $\begin{array}{l}\text { 1- Seniors and people with } \\
\text { disabilities should be expected to } \\
\text { meet the same standards as } \\
\text { nondisabled guests }\end{array}$ & 3.73 & 1.16 & 74.6 & High & 1 & 3.08 & 1.73 & 61.6 & average & 3 \\
\hline $\begin{array}{l}2 \text { I'm always experiencing many } \\
\text { problems while dealing with } \\
\text { people with disabilities and } \\
\text { seniors during their } \\
\text { accommodation time }\end{array}$ & 3.28 & 1.33 & $\begin{array}{c}65 . \\
6\end{array}$ & average & 3 & 3.41 & 1.36 & 68.2 & high & 2 \\
\hline $\begin{array}{l}\text { 3- I prefer not to deal directly } \\
\text { with people with disabilities and } \\
\text { seniors }\end{array}$ & 2.69 & 1.08 & $\begin{array}{c}53 . \\
8\end{array}$ & average & 6 & 2.89 & 1.61 & 57.8 & average & 4 \\
\hline $\begin{array}{l}4 \text {-Seniors and people with } \\
\text { disabilities should be isolated } \\
\text { from nondisabled guests }\end{array}$ & 2.52 & 1.25 & $\begin{array}{c}50 . \\
4\end{array}$ & Low & 7 & 2.79 & 1.07 & 55.8 & average & 6 \\
\hline $\begin{array}{l}5 \text { People with disabilities are less } \\
\text { frequently travelling because of } \\
\text { their disability }\end{array}$ & 3.66 & 1.25 & $\begin{array}{c}73 . \\
2\end{array}$ & High & 2 & 2.72 & 1.37 & 54.4 & average & 7 \\
\hline $\begin{array}{l}\text { 6- I offer help to people with } \\
\text { disabilities and seniors even if it } \\
\text { not being requested }\end{array}$ & 3.15 & 1.22 & 63 & average & 5 & 2.86 & 1.53 & 57.2 & average & 5 \\
\hline $\begin{array}{l}\text { 7- I feel uncomfortable while } \\
\text { dealing with people with } \\
\text { disabilities and seniors }\end{array}$ & 2.17 & 1.29 & $\begin{array}{c}43 . \\
4\end{array}$ & Low & 8 & 1.75 & 1.14 & 35 & $\begin{array}{l}\text { Very } \\
\text { low }\end{array}$ & 8 \\
\hline $\begin{array}{l}\text { 8- I try to behave normally and } \\
\text { ignore the person's disability }\end{array}$ & 3.20 & 1.51 & 64 & average & 4 & 3.96 & 1.13 & 73.8 & high & 1 \\
\hline Total mean & 3.05 & 1.10 & 61 & avera & & 2.93 & 1.36 & 58.6 & Aver & age \\
\hline
\end{tabular}

It is clear from table (2) that the attitudes of hotel employees in the Egyptian travel and tourism sector towards seniors and PWDs is neutral (Mean =3.05), where the highest response of staff attitude towards seniors and PWDs came to the statement (1) which states that seniors and people with disabilities should be expected to meet the same standards as nondisabled guests. On the other side, the attitudes of travel agencies employees in the Egyptian travel and tourism sector towards seniors and PWDs is neutral (Mean $=2.93$ ), while the highest response of staff attitude towards seniors and PWDs came to the statement (8) which states I try to behave normally and ignore the person's disability . This indicates that the attitude of hotels and travel agents' staff are against the medical model of disability 
(where the person with a disability carries the blame). However, it is evident that neutral attitudes can be interpreted as an unwillingness to express their true attitude towards Accessible tourism market, the thing which may be more socially desirable.

The level of training of the Egyptian human resources in tourism sector on Accessible Tourism:

The research used some tools of descriptive statistics in order to analyze the level of training of the Egyptian human resources in tourism sector on Accessible Tourism.

Table (3) shows the mean, S.D, Percent (\%) and the level of verification related to the level of training of the Egyptian human resources in tourism sector towards Accessible Tourism as the following:

Table 3

The level of training of the Egyptian human resources in tourism sector on Accessible Tourism

\begin{tabular}{|c|c|c|c|c|c|c|c|c|c|c|}
\hline \multirow[b]{2}{*}{ Item } & \multicolumn{5}{|c|}{ Hotel employees } & \multicolumn{5}{|c|}{ travel agencies employees } \\
\hline & \begin{tabular}{|c|} 
mea \\
n
\end{tabular} & S.D & $\%$ & $\begin{array}{c}\text { Level of } \\
\text { verification }\end{array}$ & order & mean & S.D & $\%$ & \begin{tabular}{|c|} 
Level of \\
verification
\end{tabular} & Order \\
\hline $\begin{array}{l}\text { 1-I'm in need of Accessible } \\
\text { Tourism awareness training } \\
\text { programs in the property }\end{array}$ & 3.82 & 1.20 & 76.4 & High & 2 & 3.48 & 1.23 & 69.6 & High & 3 \\
\hline $\begin{array}{l}2 \text {-I'm in need of specific skills to } \\
\text { deal with PWDs and seniors } \\
\text { effectively }\end{array}$ & 3.58 & 1.43 & 71.6 & High & 3 & 4.20 & 0.93 & 84 & High & 1 \\
\hline $\begin{array}{l}\text { 3- Taken an Accessible Tourism } \\
\text { awareness training program before }\end{array}$ & 4.28 & 1.09 & 85.6 & Very high & 1 & 4.00 & 0.95 & 80 & High & 2 \\
\hline $\begin{array}{l}4 \text {-The program contributed in } \\
\text { changing attitudes towards } \\
\text { Accessible Tourism }\end{array}$ & 1.28 & 0.45 & 25.6 & Very low & 5 & 1.27 & 0.45 & 25.4 & Very low & 5 \\
\hline $\begin{array}{l}\text { 5- The best training tool for the } \\
\text { training program }\end{array}$ & 3.03 & 0.99 & 60.6 & Average & 4 & 2.86 & 0.98 & 57.2 & Average & 4 \\
\hline Total mean & 3.20 & 1.03 & 64 & Avera & & 3.16 & 0.90 & 63.2 & Avera & \\
\hline
\end{tabular}

Results: It is clear from the table (3) that the training of hotel employees in the Egyptian travel and tourism sector in Accessible Tourism is average (Mean =3.20), where the highest response of staff training came to the statement (3) which states have you ever taken an Accessible Tourism awareness training program. The thing which points to the need of an effective Accessible Tourism awareness training programs among hotel staff. On the other side, the training of travel agencies employees in the Egyptian travel and tourism sector in Accessible Tourism is average too (Mean $=3.16$ ), where the highest response of staff training came to the statement (2) which states I am in need for specific skills to deal with PWDs and seniors effectively. This can attributed to the lack of effective training programs which enhance the skills of travel agents' staff in the field of Accessible Tourism.

\section{Conclusion:}

The growing market of Accessible Tourism presents a strong challenge to the Egyptian tourism sector to meet different needs in terms of mobilizing the investments in human resources, enhancing policies and engaging both the private and public sectors so as to serve such an important and promising market sector. Indeed one of the common complaints is the negative attitudes of tourism staff towards people with disabilities and seniors, such attitudes are mainly because of lack of awareness of the different requirements of people with disabilities and seniors as well as the potential market of Accessible Tourism.

The paper has examined the role of Accessible Tourism awareness training in changing attitudinal barriers, however; there is a lack of effective Accessible Tourism training 
programs. In particular, using the outcomes of this research, the tourism sector may implement effective training program on Accessible Tourism for all the human resources along the chain so as to have a professional tourism staff capable of dealing with the Accessible Tourism market in an effective and tailored way.

\section{Recommendations}

- In order to tackle the barriers facing people with disabilities and seniors in Egypt; the research suggests that the Ministry of Tourism in Egypt should focus on the following: promoting the awareness of employees and local community through forums and conferences, promoting in collaboration with organizations concerned with people with disabilities for the exchange of useful information and experience.

- Tourism Development Authority should encourage stakeholders to invest in the field of Accessible Tourism.

-Travel agencies employees ought to be trained to provide safe, enjoyable and comfortable tourism experiences for the entire tourism market, including individuals with disabilities, seniors and others with special access requirements.

\section{References}

- Buhalis, D. and Darcy, S. (2011). Accessible Tourism: concepts and issues, Bristol: Channel View Publications.

- Darcy, S. and Pegg, S. (2011).'Towards strategic intent: perceptions of disability service provision amongst hotel accommodation sector managers'. International Journal of Hospitality Management, vol.30 (2), pp.468-476.

- Daruwalla, S. and Darcy, S. (2005).'Personal and societal attitudes to disability'. Annals of Tourism Research.vol.23 pp.549-570.

- ENAT" European Network for Accessible Tourism. (2007). Services and Facilities for Accessible Tourism in Europe, Athens, Greece.

- ENAT and European Commission (2013) "Mapping skills and training needs to improve accessibility in tourism services", available at: 〈http://www.accessibletourism.org/?i=enat.en.enat_projects_and_good_practices.1408 2

"Mapping skills and training needs to improve accessibility in tourism services last accesses 2/5/2016.

- European Commission. (2010). Communication from the Commission to the European Parliament, the Council, the European Economic and Social Committee and the Committee of the Regions. European disability strategy 2010-2020: A renewed commitment to a barrier-free Europe.

- Gillovic, B. and McIntosh, A. (2015). 'Stakeholder perspectives of the future of accessible tourism in New Zealand', Journal of Tourism Futures.Vol.1 issue: 3, pp.223-239.

- Groot, R. and Molen, P. (2000). Workshop on capacity building in land administration for development countries: final report, ITC: The Netherlands.

- Kaganek, K.; Ambroży,T.; Mucha, D.; Jurczak, A.; Bornikowska, A.; Ostrowski, A.; Janiszewska, R. and Mucha, T. (2017). Barriers to Participation in Tourism in the Disabled, Polish Journal of Sport and Tourism.vol.4, pp.121-129.

- Mallick, S. (2013). Capacity Building: Concept, Definition and Methodology for Self Assessment.ANSN/ETTG Annual Meeting Vienna. 
- Michopoulou, E., Darcy, S., Ambrose, I. and Buhalis, D. (2015). Accessible tourism futures: the world we dream to live in and the opportunities we hope to have.Journal of tourism. vol.1 (3). pp.179-187.

- UNWTO. (2013). Update of the 2005 UNWTO General Assembly Recommendations on "Accessible Tourism for All", taking into consideration the UN Convention on the Rights of Persons with Disabilities of 2007. Spain.

- UNWTO (2016). Accessible Tourism for All: An Opportunity within Our Reach. Madrid. Spain

- Yamoah. E. (2014). The Link between Human Resource Capacity Building and Job Performance. International Journal of Human Resource Studies. Vol. 4, No. 3, pp.139-146.

- Zheng, Q.; Tian, Q.; Hao, C.; Gu, J.; Tao, J.; Liang, Z.; Chen, X.; Fang, J.; Ruan, J.; Ai , Q. and Hao, Y. (2016). Comparison of attitudes toward disability and people with disability among caregivers, the public, and people with disability: findings from a cross sectional survey, BMC Public Health, Vol. 16, No. 1, pp. 1-10.

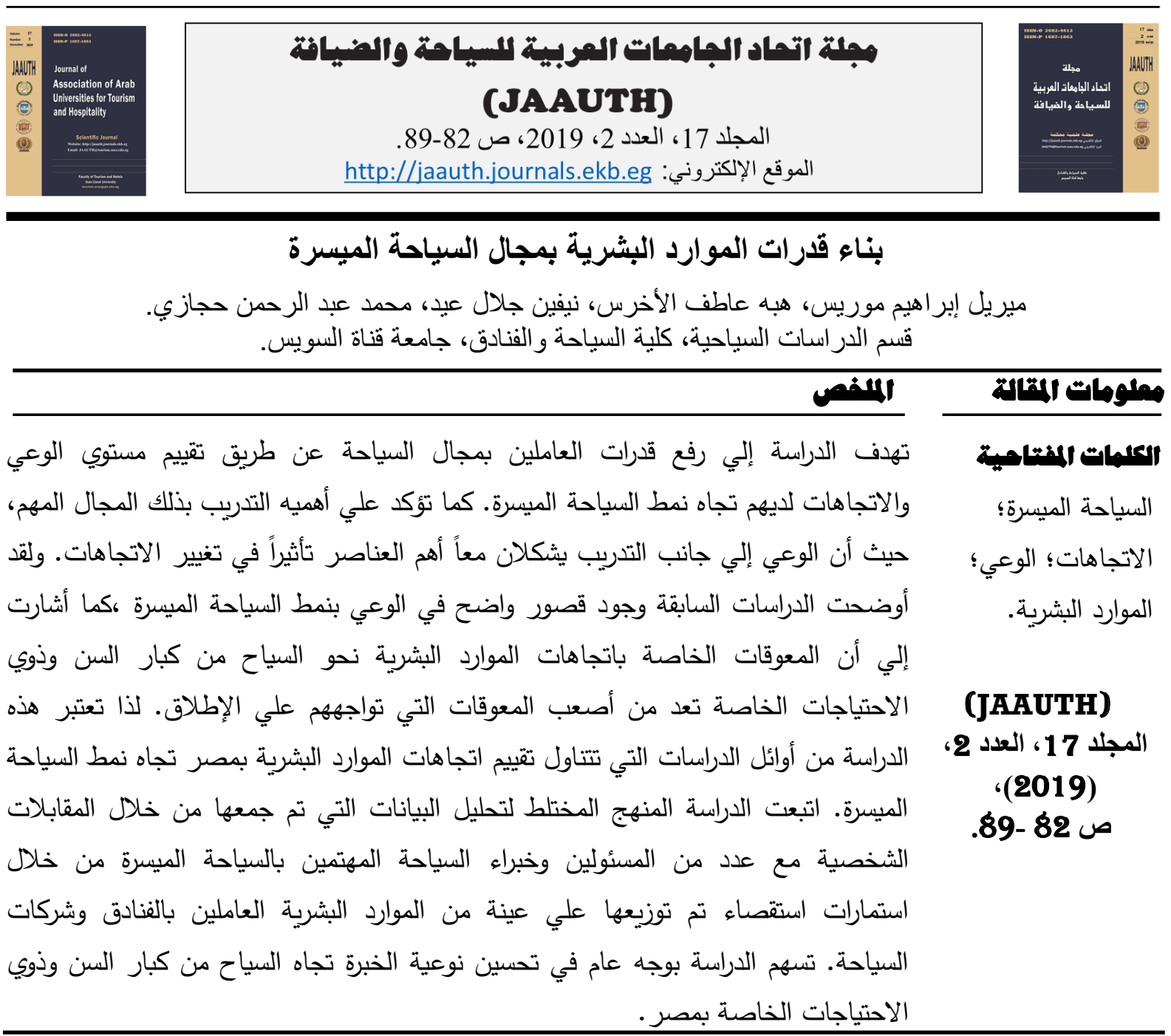

